\title{
Acquired resistance of rock bream (Oplegnathus fasciatus) against rock bream iridovirus (RBIV) through undergoing low water temperature period
}

\author{
Kosuke Zenke, Ki Joon Yoon*, Min Sun Kim*, \\ Seung Hyuk Choi* ${ }^{* *}$ and Ki Hong Kim ${ }^{* *+}$ \\ Department of Aquatic Bioscience, Graduate School of Agricultural and Life Sciences, \\ The University of Tokyo, Tokyo, 113-8657, Japan \\ "Hebei Spirit Incident Compensation Bureau, Ministry of Oceans and Fisheries, Sejong-si 339-012, Korea \\ ${ }^{* *}$ Department of Aquatic Life Medicine, Pukyong National University, Pusan 608-737, Korea
}

\begin{abstract}
Water temperature is a key environmental factor controlling the epizootics of viral diseases in fish. High water temperature is associated with the rapid spread of rock bream iridovirus (RBIV) disease and with high mortality of RBIV infected fish. Although protection of fish against iridoviral disease by active immunization has been reported, little information is available concerning whether fish survived from an epizootic of iridoviral disease can naturally acquire resistance against the viral disease. In the present study, we have demonstrated that juvenile rock bream, which survived from a natural epizootic of RBIV, acquired resistance against recurrence or reinfection of RBIV, and this resistance was established during the subsequent low water temperature period. Furthermore, the possible involvement of the adaptive humoral immune response in the resistance of the juvenile rock bream was suggested by in vivo neutralization experiment.
\end{abstract}

Key words: Rock bream iridovirus (RBIV), Low temperature period, Rock bream, Virus clearance, Acquired resistance

Iridoviruses are large, icosahedral, cytoplasmic viruses with a double-stranded DNA genome (Williams, 1996). In the family of Iridoviridae, 5 genera - Iridovirus, Lymphocystivirus, Chloriridovirus, Ranavirus and Megalocytivirus - have been recorded (Chinchar et al., 2005). In Korea, high mortalities by Megalocytivirus infections in net-caged juvenile rock bream, Oplegnathus fasciatus, occurred firstly at 1998. Since then, the iridoviral disease has been the major culprit of mass mortality of cultured rock

${ }^{\dagger}$ Corresponding author: Ki Hong Kim

Tel: +82-51-629-5943, Fax: +82-51-629-5938

E-mail: khkim@pknu.ac.kr bream in Korea (Sohn et al., 2000; Jung and Oh, 2000; Kim et al., 2002; Do et al., 2004).

Water temperature is a key environmental factor controlling the epizootics of viral diseases in fish. High water temperature (from late summer to early autumn in Korea) is associated with the rapid spread of rock bream iridovirus (RBIV) disease and with high mortality of RBIV infected fish. In contrast, decrease of mortality and rapid recovery of RBIV-infected fish are associated with decline of water temperature below $20^{\circ} \mathrm{C}$. Although protection of fish against iridoviral disease by active immunization with formalin-killed virus (Nakajima et al., 1997, 1999) or DNA vaccine (Caipang et al., 2006) has 
been reported, little information is available concerning whether fish survived from the epizootic of iridoviral disease can naturally acquire resistance against the viral disease.

In the present study, we have demonstrated that juvenile rock bream survived from a natural epizootic of RBIV acquired resistance against recurrence or reinfection of RBIV, and this resistance was established during the subsequent low water temperature period. Furthermore, the possible involvement of the adaptive humoral immune response in the resistance of the juvenile rock bream was suggested by in vivo neutralization experiment.

\section{Materials and Methods}

\section{Fish}

Juvenile rock bream, Oplegnathus fasciatus, (average body weight, $40 \pm 0.5 \mathrm{~g}$ ) were obtained from a net-pen farm located on the southern coast of Korea at the end of October. The net-pen farm already had been experienced about $40 \sim 50 \%$ of cumulative mortality due to rock bream iridovirus (RBIV) infection, and at that time around our sampling the mortality was decreased and water temperature was $18-19^{\circ} \mathrm{C}$. The fish were transported to the laboratory, and placed in 1 ton circular tanks at $17 \pm 0.5^{\circ} \mathrm{C}$. At the day of fish arrival, 20 fish were sampled randomly, and were analyzed the presence of RBIV DNA in the spleen by polymerase chain reaction (PCR).

\section{Virus}

RBIV stock solution was prepared from the spleen of rock bream, which died from a natural epizootic of RBIV disease in a net-pen farm. The spleen was homogenized in minimum essential medium (MEM; GIBCO), and cell debris was removed by several centrifugations at $5000 \mathrm{rpm}$ for $10 \mathrm{~min}$ at $4^{\circ} \mathrm{C}$. Supernatant was then filtered through 0.2 $\mu \mathrm{m}$ syringe filter (Advantech), and used as virus stock solution.

\section{Polymerase chain reaction (PCR)}

Genomic DNA was isolated from the spleen of rock bream using Accuprep ${ }^{\circledR}$ Genomic DNA Extraction Kit (Bioneer Co., Korea). Two oligonucleotide primers, PF (5'-ATGTCTGCAATCTCAGGTG-3') and PR (5'-TTACAGGATAGGGAAGCCTGC-3') were designed to amplify the major capsid protein (MCP) ORF of RBIV (GenBank accession number, AY532612), and the expected size of amplification product was $1362 \mathrm{bp}$. The PCR amplification procedure was carried out in a $10 \mu \mathrm{l}$ reaction mixture containing $5 \mu \mathrm{l}$ of PCR premix taq (Takara), $0.5 \mu 1$ (10 $\mu \mathrm{M})$ of each primer, $1 \mu \mathrm{l}(300 \mathrm{ng})$ of DNA template, and distilled water. The reaction was performed for a first pre-denaturation step of $3 \mathrm{~min}$ at $95^{\circ} \mathrm{C}$ followed by 30 cycles of $95^{\circ} \mathrm{C}$ for $0.5 \mathrm{~min}, 50^{\circ} \mathrm{C}$ for $0.5 \mathrm{~min}$ and $72^{\circ} \mathrm{C}$ for $1.0 \mathrm{~min}$., with a final extension step of $7 \mathrm{~min}$ at $72^{\circ} \mathrm{C}$ using an automated thermal cycler (iCycler, BioRad). Oligonucleotide primers, NF (5'-CACCGCAACGTGCAAAGCAA-3') and NR (5'-TTGACTGCAATAACGACCAGTTCAAAC-3') were used for nested-PCR, and the expected size of amplification product was $398 \mathrm{bp}$. DNA template of the nested-PCR was $1 / 10$ dilution of the first PCR products, and the reaction condition was as described above. PCR product was analyzed by electrophoresis on a $0.7 \%$ agarose gel.

Resistance of juvenile rock bream against recurrence or reinfection of RBIV

To know whether the collected juvenile rock bream, kept at $17 \pm 0.5^{\circ} \mathrm{C}$ in laboratory tanks, were resistant against recurrence of RBIV disease, after 3 days of the arrival, 20 fish were transferred to a 400 1 tank, and water temperature was elevated to $25^{\circ} \mathrm{C}$ by increment of approximately 2 degrees per day. Similarly, 20 fish kept for 1 month at $16 \sim 17^{\circ} \mathrm{C}$ were treated the same way as above. After 2 months of keeping the fish at low temperature, in order to determine whether the fish acquired resistance against reinfection of RBIV, 20 randomly sampled 
fish were transferred to a 4001 tank, and water temperature was gradually elevated to $25^{\circ} \mathrm{C}$, and then, the fish were intraperitoneally (i.p.) injected with 100 $\mu 1$ of $4^{-1}$ diluted RBIV stock. Group of fish kept at $25^{\circ} \mathrm{C}$ without RBIV injection was used as a control. Fish died during the experiments were deep-freezed at $-70^{\circ} \mathrm{C}$ until PCR analysis. At 21 days post temperature elevation in the second recurrence and the reinfection experiments, surviving fish were anaesthetized with MS222 (Sigma) and peripheral blood was collected from the tail vein for in vivo neutralization analysis, and then spleen was excised for PCR analysis.

At early in April of the following year, over-wintered juvenile rock bream were sampled from the fish farm, and were analyzed the presence of RBIV DNA by PCR.

\section{In vivo neutralization}

Fingerling rock bream $(2.5 \pm 0.3 \mathrm{~g}$ in body weight) were obtained from a hatchery, and were acclimated for 2 weeks at $18^{\circ} \mathrm{C}$ prior to the experiment. Serum samples obtained from the above surviving juvenile rock bream and the naïve fingerling were heat inactivated at $53^{\circ} \mathrm{C}$ for $0.5 \mathrm{~h}$, and mixed with the virus prior to inoculation. A total of 60 fingerling were randomly divided into 5 groups (group I - group V), and placed in five 501 tanks of 12 fish. Fish of group I were injected intramuscularly (i.m.) with 10 $\mu 1$ of phosphate buffered saline (PBS) as control. Fish of group II - group V were injected i.m. with $5 \mu \mathrm{l}$ of $5 \times 10^{-3}$ diluted RBIV stock solution plus 5 $\mu 1$ of PBS (group II), $5 \mu$ of heat-inactivated naïve serum (group III), $5 \mu \mathrm{l}$ of heat-inactivated serum of fish recovered from above RBIV recurrence experiment (group IV), or $5 \mu \mathrm{l}$ of heat-inactivated serum of fish recovered from above RBIV reinfection experiment (group V), respectively. From the day of injection, water temperature was gradually raised to $25{ }^{\circ} \mathrm{C}$ and mortality of fish was monitored 4 times daily.

\section{Results and Discussion}

All juvenile rock bream randomly sampled at the day of arrival in the laboratory were positive for RBIV by primary PCR. Fish kept below $18^{\circ} \mathrm{C}$ in the laboratory tanks for 3 days showed $100 \%$ mortality within 2 weeks by elevation of water temperature to $25^{\circ} \mathrm{C}$. The dead fish showed splenomegaly and were positive for RBIV by primary PCR (Fig. 1a). This result suggests that the decrease of mortality in the fish farm at the time around our sampling might be not by acquisition of resistance of fish but by decrease of viral replication or virulence according to decline of water temperature.

After 1 month of keeping the fish below $18^{\circ} \mathrm{C}$ in the laboratory tanks, all randomly sampled fish were negative for amplification of RBIV MCP gene by primary PCR, but among them, some fish were positive for RBIV by nested PCR. Moreover, no fish

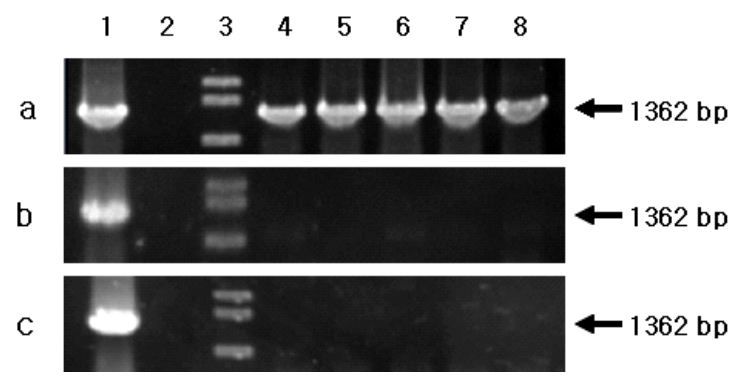

Fig. 1. Primary PCR detection of rock bream iridovirus (RBIV) DNA from the spleen of juvenile rock bream (Oplegnathus fasciatus). (a) Fish died from the first RBIV recurrence experiment. Fish were kept below 18 ${ }^{\circ} \mathrm{C}$ in the laboratory tanks for 3 days and elevated water temperature to $25^{\circ} \mathrm{C}$. (b) Fish survived from the second RBIV recurrence experiment. Fish were maintained below $18^{\circ} \mathrm{C}$ in the laboratory tanks for 1 month and elevated water temperature to $25^{\circ} \mathrm{C}$. (c) Fish survived from RBIV reinfection experiment. Fish were kept for 2 months below $18^{\circ} \mathrm{C}$ and were intraperitoneally injected with RBIV (water temperature $25^{\circ} \mathrm{C}$ ). Lane 1 , positive control ; Lane 2, negative control; Lane 3, 1-kb marker (Bioneer); Lane 4-8, each lane represents different fish. PCR products and markers were analyzed by agarose gel electrophoresis and ethidium bromide staining. 
were died by elevation of water temperature to $25^{\circ} \mathrm{C}$, and all the surviving fish were negative for RBIV by primary PCR (Fig. 1b). These results suggest the clearance of RBIV from the fish during the low temperature period, and fish may have acquired resistance during that period against recurrence of RBIV.

Fish kept at low temperature for 2 or 3 months were also negative for RBIV by PCR amplification. Similarly, rock bream over-wintered at the fish farm and collected at April of the following year showed also negative for RBIV by primary and nested PCR.

In this study, fish kept for 2 months below $18^{\circ} \mathrm{C}$ showed no mortality and no PCR positive for RBIV by intraperitoneal injection of RBIV plus water temperature up-shift to $25^{\circ} \mathrm{C}$ (Fig. 1c). These results suggest that juvenile rock bream acquired resistance against reinfection of RBIV and specific immune responses might be involved in the clearance of infected RBIV.

Because of rapid decrease of RBIV infectivity during serial passages in a wide range of fish cell lines, the RBIV stock used in the present infection experiments was made from spleens of fish infected by RBIV. Moreover, although several attempts have been made to determine $L_{50}$ dose of the RBIV stock, there were no differences in mortalities of rock bream injected with the RBIV stock diluted from 1 $\times 10^{-3}$ to $1 \times 10^{-7}$, and increase of the dilution ratio only lengthened the days to death. Therefore, the dilution of the RBIV stock eliciting $100 \%$ mortality of the rock bream fingerlings between 1-2 weeks was used as the present infection dose. In the present in vivo neutralization experiment, although all experimental groups showed $100 \%$ mortality, rock bream fingerlings injected with RBIV plus sera obtained either from the recurrence experiment or from the re-infection experiment showed delayed mortality when compared to control fish administered RBIV plus either naïve rock bream sera or PBS buffer (Fig. 2 ). As we could not conduct in vitro neutralization assays, the titer of neutralizing antibodies in the con-

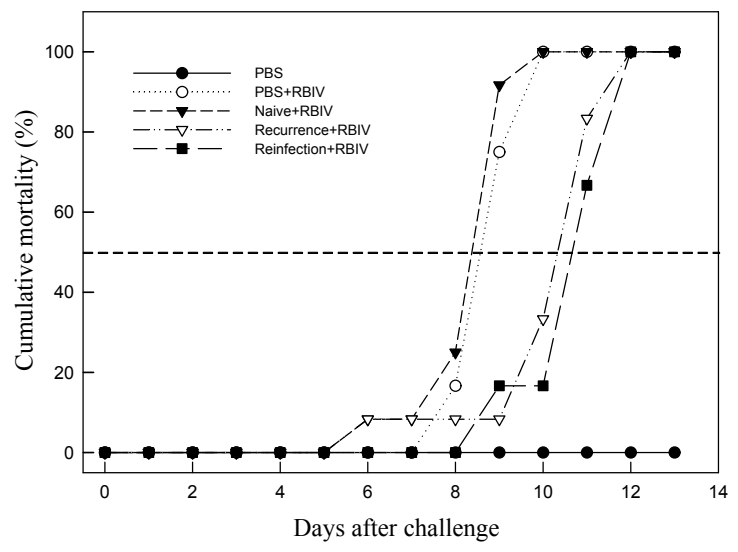

Fig. 2. Cumulative mortality of rock bream (Oplegnathus fasciatus) fingerling injected with rock bream iridovirus (RBIV) plus sera obtained from - fish survived from the RBIV recurrence experiment (Recurrence+RBIV), fish survived from the RBIV reinfection experiment (Reinfection+RBIV), or naïve rock bream (Naïve+RBIV). Fingerling injected with RBIV plus PBS (PBS+RBIV) or with PBS alone (PBS) were used as the positive and the negative control groups, respectively.

valescent sera was not determined. However, the present result suggests the possible involvement of humoral adaptive immune responses in the acquired resistance of the juvenile rock bream.

The present results suggest that water temperature can be used to control RBIV disease in juvenile rock bream. However, lowering water temperature in fish farms, especially in net-caged farms, is not practical or not executable. Therefore, extension of the survival period of fish infected with RBIV until water temperature decrease below $20^{\circ} \mathrm{C}$ by enhancing antiviral activity of fish would be more executable. Further studies are needed to elucidate the duration of the acquired resistance, cellular immune factors involved in the resistance, and methods to enhance antiviral activity including effective vaccines.

\section{References}

Caipang, C.M.A., Takano, T., Hirono, I. and Aoki, T.: Genetic vaccines protect red seabream, Pagrus major, upon challenge with red seabream iridovirus 
(RSIV). Fish Shellfish Immunol., 21: 130-138, 2006. Chinchar, V.G., Essbauer, S., He, J.G., Hyatt, A., Miyazaki, T., Seligy, V. and Williams, T.: Family Iridoviridae. In: Virus Taxonomy. Eighth Report of the International Committee on Taxonomy of Viruses (ed. by C.M. Fauquet, M.A. Mayo, J. Maniloff, U. Desselberger \& L.A. Ball), pp. 145-162. Academic Press, San Diego, CA, 2005.

Do, J.W., Moon, C.H., Kim, H.J., Ko, M.S., Kim, S.B., Son, J.H., Kim, J.S., An, E.J., Kim, M.K., Lee, S.K., Han, M.S., Cha, S.J., Park, M.S., Park, M.A., Kim, Y.C., Kim, J.W. and Park, J.W.: Complete genomic DNA sequence of rock bream iridovirus. Virology, 325: 351-363, 2004.

Jung, S.J. and Oh, M.J.: Iridovirus-like infection associated with high mortalities of striped beakperch, Oplegnathus fasciatus (Temminck et Schlegel) in southern coastal areas of the Korean peninsula. J. Fish Dis., 23: 223-226, 2000.
Kim, Y.J., Jung, S.J., Choi, T.J., Kim, H.R., Rajendran, K.V. and Oh, M.J.: PCR amplification and sequence analysis of irido-like virus infecting fish in Korea. J. Fish Dis., 25: 121-124, 2002.

Nakajima, K., Maeno, Y., Kurita, J. and Inui, Y.: Vaccination against red sea bream iridoviral disease in red sea bream. Fish Pathol., 32: 205-209, 1997.

Nakajima, K., Maeno, Y., Honda, A., Yokoyama, K., Tooriyama, K. and Manabe, S.: Effectiveness of a vaccine against red sea bream iridoviral disease in a field trial test. Dis. Aquat. Org., 36: 73-75, 1999. Sohn, S.G., Choi, D.L., Do, J.W., Hwang, G.Y. and Park, J.W.: Mass mortalities of cultured striped beakperch, Oplegnathus fasciatus by iridoviral infection. J. Fish Pathol., 13: 121-127, 2000 (in Korean with English abstract).

Williams, T.: The iridoviruses. Adv. Virus Res., 46: 345412, 1996.

Manuscript Recceived : July 10, 2014

Revised : August 13, 2014

Accepted: August 13, 2014 